\section{ПЛАНУВАННЯ ЗРОСТАННЯ ПОТУЖНОСТІ МОРСЬКИХ ПОРТІВ}

\section{SEAPORT POWER GROWTH PLANNING}

\author{
НІКОЛАЄВА Л. Л., \\ доктор економічних наук, \\ професор, \\ БЕРЕЗА В. В., \\ кандидат економічних наук, \\ доцент, \\ СМОЛЕЦЬ В. В., \\ кандидат економічних наук, \\ доцент, Національний університет \\ «Одеська морська академія»
}

\author{
NIKOLAIEVA L., \\ Doctor of Science in Economics, \\ Professor, \\ BEREZA V., \\ PhD in Economics, Associate \\ Professor, \\ SMOLETS V., \\ PhD in Economics, Associate \\ Professor, National University \\ "Odessa Maritime Academy»
}

У статті наголошується про необхідність планування потужностей портів. Доведено зв'язок конкурентоспроможності порту та збільшення його потужності. Встановлено, що управління потенціалом включає планування та реалізацію потенціалу, а планування потенціалу включає проєктування, оцінку та фінансування. Підкреслено, що пропускна спроможність порту представляє баланс між покращеною якістю обслуговування та впливом на добробут суспільства й інвестиційними витратами на покращення пропускної спроможності.

Ключові слова: планування потужності, управління потенціалом, ефективна потужність, пропускна спроможність.

В статье подчеркивается необходимость планирования пропускной способности портов. Доказана связь между конкурентоспособностью порта и увеличением его пропускной способности. Было установлено, что управление мощностью включает планирование и реализацию мощности, а планирование мощности включает проектирование, оценку и финансирование. Подчеркивается, что пропускная способность порта представляет собой баланс между улучшенным качеством обслуживания и влиянием на благосостояние общества, а также инвестиционными затратами на повышение пропускной способности.

Ключевые слова: планирование мощности, управление мощностью, эффективная мощность, пропускная способность.

The article emphasizes the need for port capacity planning. The connection between the competitiveness of the port and the increase of its capacity has been proved. Capacity management has been found to include capacity planning and implementation, and capacity planning includes design, evaluation and financing. It is emphasized that the port capacity represents a balance between improved service quality and the impact on the welfare of society and investment costs to improve capacity.

Key words: capacity planning, capacity management, effective capacity, throughput.

Постановка проблеми. В останні роки спостерігаються стрімкі зміни в логістиці та транспортних технологіях. Наприклад, посилення уваги до ефективності ланцюга поставок призвело до контейнеризації, що спричинило революцію у проєктуванні та експлуатації режимів вантажних перевезень та обробки вантажів. Це, у свою чергу, послужило стимулом для інтеграції послуг морського та наземного транспорту, що робить логістичні ланцюги більш гнучкими (тобто менш прив'язаними до певних транспортних шляхів). 
Як результат, міжнародні вантажні потоки стали більш мінливими, що спричинило постійний тиск на порти, щоб вони залишались конкурентоспроможними. Портові інвестиції по суті спрямовані на більш ефективні процеси обробки вантажів. Це спричинює насамперед виграш у транспортній ефективності - зменшення часу обслуговування та витрат - для портових споживачів (вантажних перевізників) та комерційні вигоди для портових операторів, що представляють приватну мету портових інвестицій. Якщо перевага транспортної ефективності передається суспільству, це призводить до кінцевої (державної) мети портових інвестицій, а саме: «збільшити надлишок виробників тих, хто здійснює експорт, що проходить через нього, і збільшити надлишок споживачів ті, хто зрештою споживає імпорт, що проходить через нього».

Аналіз останніх досліджень і публікацій. Значна частина наукової літератури щодо зростання потужності портів розподілена за різними суміжними дисциплінами, таких як будівництво та економіка. Завдання полягає у поєднанні знань з цих дисциплін для розробки підґрунтя планування портового потенціалу. Дослідженням питань інвестиційних проєктів розвитку сучасних портів присвятили свої праці не тільки теоретика, але й практики: Янсонс Дж [1], Куперс Б., Маншанден У. [2], Ашфорд Н. [3], Деккер С. [4], Баирд А. [5]. 3 роками значення та актуальність розвитку інфраструктури порту тільки підсилюється й потребує нових ідей та пошуків.

Метою статті є планування розвитку потужностей морських портів.

Виклад основного матеріалу. Термін інфраструктура, згідно Янсонсу Дж., походить від латинського слова "infra", що означає «розташований нижче» [1]. Спочатку це був військовий термін, що позначав статичну та фізичну основу матеріально-технічної організації, таку як дороги, мости, сховища та трубопроводи. Нині термін інфраструктура також використовується для невійськових об'єктів і розглядається як основна потреба суспільств у підтримці подальшого розвитку. Прикладами посилань є дороги, залізниці та канали; вузли включають залізничні станції, термінали, морські порти та аеропорти. Місткість $є$ важливою характеристикою інфраструктури, що свідчить про її здатність надавати певну послугу, таку як відправлення вантажів. Зміни в потужності можуть бути виражені через час та вартість відправника. Згідно з Маншанден У. [2], ємність можна визначити як максимальну кількість предметів, які можна «пропустити» через систему або іï компоненти за одиницю часу на певному рівні якості відправника. Наприклад, місткість контейнерного порту може бути виражена кількістю контейнерів, які можна обробляти за рік. Ефективна потужність визначається наступними характеристиками [3]: змінними конструкції, такими як кількість, розміри та площі поверхонь; якістю та надійністю послуг, що визначаються робочою силою, застосованими технологіями та графіками відправлення; характер попиту, такий як швидкість прибуття та характеристики обробки транспортованих предметів; факторами навколишнього середовища, такі як навколишня територія та погодні умови.

Інфраструктура тісно пов'язана з логістичними відправниками та становить для неї основний компонент. Логістичні відправники роблять значний внесок у економіку країни. Усвідомлюючи важливість логістики для національної економіки, Голландська консультативна 
рада 3 питань транспорту, благоустрою та управління водними ресурсами ініціювала дослідження щодо інновацій у логістиці. Результатом цього дослідження у 2003 році стала порада, адресована уряду Нідерландів [4]. Він підкреслює важливість ефективних логістичних систем для конкурентоспроможності голландської економіки та необхідність впровадження політики, яка підтримує позиції Нідерландів у міжнародній логістиці. Усунення вузьких місць в інфраструктурі вважається вирішальним викликом для такої політики на найближчі роки.

Планування інфраструктури по суті полягає у встановленні оптимальної потужності у відповідний час та місці. Тип міри потенціалу (фізичне розширення або менш капіталомісткі альтернативи) $€$ основною проблемою. Інша важлива, але залежна проблема полягає в оптимальному використанні доданих об'єктів. Наприклад, попит на отримувачів перевезень у ланках транспортної мережі в значною мірою залежить від рівня перевантаження трафіку в ланках, який, у свою чергу, залежить від рівня використання [2].

Починаючи з визначення попиту на отримувачів, слід встановити відповідну пропозицію потужності, що призведе до певних витрат. Повний аналіз дозволить визнати, що витрати впливають на ціну, що стягується для відправників, що, в свою чергу, впливає на попит.

у літературі можна знайти кілька визначень планування та управління потенціалом. Посилаючись на Бард А., управління потенціалом можна визначити як сукупність рішень, що призводять до певної якості, включаючи правила, що використовуються для реалізації потенціалу [5]. Тут планування потужності визначатиметься як технікоекономічний аналіз відповідності пропозиції потужності попиту на послуги певної якості та розробка альтернативних варіантів покращення відповідності. Слід розрізняти оперативне планування, яке наголошує на тому, що повинен робити оператор інфраструктури, щоб мати справу з короткостроковими (наприклад, щоденними) коливаннями попиту на певну потужність, та стратегічне планування, яке робить акцент на довгостроковому наданні послуг власником інфраструктури. Сфера цього дослідження - стратегічне планування.

Потім управління пропускною спроможністю визначатиметься як управлінська реакція власника інфраструктури на проблеми обслуговування (дефіцит потужності та надмірна потужність). Рішення щодо управління потенціалом базуються на результатах планування потенціалу. Такі рішення можуть бути складними через, наприклад, складність у визначенні прийнятного рівня якості послуги (наприклад, затори).

Управління потенціалом включає планування та впровадження потенціалу, а планування потенціалу включає проєктування, оцінку та фінансування $[2,5]$. Структура передбачає процес аналізу попиту та розробку альтернативних варіантів впливу на попит.

Оцінка стосується процесу оцінки відшкодування витрат/прибутковості, ефективності та справедливості, пов'язаних 3 альтернативними варіантами.

Загалом можна виділити три сфери оцінки: фінансову, економічну та соціальну. У цьому порядку вони представляють дедалі складнішу ситуацію 3 власником/користувачем. Для альтернатив, які розглядаються з чисто комерційної точки зору, фінансового обсягу буде достатньо, коли баланс грошових потоків та ліквідність $€$ 
найбільш важливими аспектами для отримання відшкодування витрат /прибутковості.

Для інвестиційних проєктів, які фінансуються урядом, також слід враховувати громадську перспективу, яка включає економічні та соціальні сфери [4].

[5]:

Економічний огляд охоплює питання економічної ефективності

1) прямі ефекти (економія витрат для користувачів та оператора),

2) непрямі ефекти (ефекти, що передаються третім сторонам через механізм ціноутворення, наприклад, мультиплікаційні ефекти),

3) зовнішні ефекти (ефекти, що переходять за межі механізму ціноутворення через, наприклад, затори на дорогах та забруднення навколишнього середовища).

Соціальна сфера вирішує проблему власного капіталу, яка включає розподіл витрат та вигод за часом та між групами та місцезнаходженням.

Нещодавно завершено дослідження щодо оцінки інвестицій в інфраструктуру (OEl; Overzicht Effectcn Infrastructuur), ініційоване урядом Нідерландів, кінцевою метою якого $€$ вдосконалення процесу прийняття рішень щодо таких інвестиції. Протягом останнього десятиліття деякі інфраструктурні проєкти породили суперечки щодо їх доцільності та значення для добробуту країни, що стимулювало ці дослідницькі зусилля. Попри те, що OEI сприяв більш прозорій та систематизованій системі оцінки, подальші дослідження повинні бути зосереджені на оцінці непрямих ефектів, а також слід приділити увагу чіткому визначенню еталонної ситуації/розвитку [4].

Фінансування - це діяльність з отримання доходів та субсидій для оплати обраного показника потужності, і вона повинна базуватися на результатах оцінки. Реалізація потенціалу включає реалізацію заходів щодо спроможності (структурних чи не структурних згідно Госс Р. та Стевенс Х. капіталомістких або менш капіталомістких згідно Декер С. для зменшення проблем із якістю обслуговування [4, 6].

Завдання планувальника - визначити оптимальний показник потужності. Його метою $є$ фінансова та економічна життєздатність відповідного інвестиційного проєкту. Морський порт - це, в основному, ділянка суші та води, де океанічні судна можна завантажувати та вивантажувати, зберігати вантажі, і де різні види транспортування у внутрішніх районах можуть збирати та доставляти вантаж. Також морський порт можна розглядати як зв'язок у глобальних транспортно-логістичних ланцюгах, що з'єднують витоки та пункти призначення вантажних потоків [2, 7].

Місткість порту, яка тут визначалася як максимальна здатність морського порту до перевезення вантажів, $\epsilon$ сукупним продуктом портових потужностей та супутніх послуг. До портових споруд належать земля, інфраструктура, надбудова, а також інфраструктура доступу до морських та внутрішніх територій. Портові послуги включають переважно послуги з обробки вантажів, які надаються за допомогою портових споруд.

Планування потужності порту ускладнюється наявністю таких питань: портово-комерційні та суспільні інтереси, конкуренція, економія від масштабу, проблеми з пропускною спроможністю та ринок порту й технологічний розвиток. Особливо взаємодія між цими проблемами ускладнює планування портів. 
Портово-комерційні та державні інтереси. Планування потужності порту вимагає розрізнення:

- По-перше, власник порту забезпечує пропускну спроможність порту. Його інтереси можна розглядати з портово-комерційної точки зору.

- По-друге, є користувачі порту, які вимагають ефективних (тобто дешевих і швидких) портових послуг. Вони представляють вантажних перевізників, морські перевізники яких вважаються найважливішими.

- Третім учасником є суспільство, яке бажає присутності портів через їхній внесок у якість життя та економічний розвиток, i встановлює межі для негативних наслідків використання портів, таких як забруднення навколишнього середовища. Уряд представляє суспільство.

3 точки зору громадськості, пропускну спроможність порту можна визначити, знайшовши баланс між покращеною якістю обслуговування користувачів порту та (індукованим) впливом на добробут суспільства, 3 одного боку, та пов'язаними 3 цим інвестиційними витратами на покращення пропускної спроможності, 3 іншого боку. Ареалістичне планування має додатково враховувати комерційні інтереси власника порту [4]. Інтереси, пов'язані з портовокомерційною перспективою, включають: максимізацію прибутку; максимізацію пропускної здатності і оздоровлення інвестицій.

Інтереси, пов'язані 3 думкою громадської перспективи: збільшення надлишку виробників з точки зору фінансових надходжень для власника порту; збільшення надлишку споживачів з точки зору покращення якості відправника для користувачів порту; ефективне використання обмежених ресурсів (наприклад, державних коштів); збільшення доданої вартості та зайнятості та зменшення забруднення навколишнього середовища; i справедливий i прозорий розподіл витрат і вигод.

Конкуренція. Загалом, портову конкуренцію можна класифікувати за шістю категоріями $[4,7]$, що включає конкуренцію між: портом або узбережжям; порти в різних країнах; окремі порти в одній країні; оператори або провайдери об'єктів в одному порту; різні (доступ/вихід) види транспорту; і ланцюги поставок.

Порти становлять вузли у складній мережі, що з'єднує витоки та пункти призначення внутрішніх районів для вантажних потоків. Визначення попиту на портові послуги по суті засноване на конкуренції між альтернативними маршрутами. Порти повинні постійно бути напоготові щодо можливих зрушень маршрутів, оскільки, наприклад, вантажні перевезення через найближчий географічний порт вже не може бути гарантованим. Програми розвитку портів також повинні враховувати можливості, які порт пропонує для всього транспортно-логістичного ланцюга, включаючи внутрішні споруди та адекватні внутрішні сполучення [7]. Багато маршрутів можна використовувати для перевезення вантажів між, наприклад, пунктами відправлення в Азії та пунктами призначення в Європі. Деякі маршрути можуть використовувати більше морського транспорту, але менше сухопутного, тому транспортні витрати невисокі, але до місця призначення може знадобитися більше часу. На інших маршрутах використовується коротша морська ділянка, але довша ділянка суші. Ці моделі витрат та часу ускладнюються через час обслуговування та тривалість роботи портів. 
Висновки та перспективи подальших досліджень. Для прийняття рішення про вибір маршруту перевізником повинні бути зроблені різні компроміси. Якщо припустити, що вантажні перевізники мають досконалу інформацію про доступні варіанти вибору маршруту, конкретний порт може вплинути на це рішення з різними стратегіями конкуренції. Фізичне розширення пропускної спроможності порту $\epsilon$ цікавою стратегією, оскільки воно призводить до поліпшення якості обслуговування (тут: зменшення витрат на затори в портах), роблячи порт більш привабливим для вантажних перевізників, і це дозволяє автономно збільшувати портовий попит.

References:

1. Jansson J. O. Transport infrastructure: the investment problem. In: Analytical Transport Economics - An International Perpective. Edward Elgar, Cheltenham, U.K. Northampton, Massachusetts, U.S. 2000. Pp. 141-171.

2. Kuipers B., W.J.J. Manshanden W. Wijnen and M.H.E. Iding Een verkenning naar de Maatschappelijke Waarde van Logistiek (Exploration of the Social Value of Logistics). TNO Inro, Delft, Netherlands, (in Dutch). 2003.

3. Ashford N., and P. H. Wright Airport Engineering. Third edition. John Wiley, New York, U.S. 1992.

4. Dekker S., Verhaeghe RJ., Economic impacts and public financing of port capacity investments: the case of Rotterdam port expansion. Transportation Research Records. No. 1820. 2003. Pp. 55-61.

5. Baird A. Analysis of private seaport development: the port of Felixstowe. Transport Policy. Vol. 6. No. 2. 1999. Pp. 109-122.

6. Goss R., and H. Stevens Marginal cost pricing in seaports. International Journal of Maritime Economics. Vol. 3. No. 2. 2001. Pp. 128-138.

7. Mcersman H., C. Steenssens and E. Van de Voorde. Container Throughput, Port Capacity and Investment. SESO, Antwerp, Belgium. 1997.

The article emphasizes that international freight flows have become more volatile, which has put constant pressure on ports to remain competitive. Port investments are essentially aimed at more efficient cargo handling processes. This primarily leads to gains in transport efficiency.

Capacity is an important characteristic of infrastructure, which indicates its ability to provide a certain service, such as shipping. Changes in power can be expressed in terms of time and cost of the sender. The characteristics of effective power are given. Infrastructure is closely linked to logistics shippers and is a key component. Logistic senders make a significant contribution to the country's economy. It is established that in the literature there are various components for capacity management and planning. Capacity management includes capacity planning and implementation, and capacity planning includes design, evaluation and financing. The assessment concerns the process of assessing the cost / profitability, efficiency and equity associated with the alternatives. In general, there are three areas of evaluation: financial, economic and social. Government-funded investment projects should 
also take into account the public perspective, which includes economic and social spheres.

The economic review covers issues of economic efficiency, namely direct effects, indirect and external effects. The social sphere solves the problem of equity, which includes the distribution of costs and benefits over time and between groups and locations. The task of the scheduler is to determine the optimal power indicator. Its purpose is the financial and economic viability of the relevant investment project.

Port capacity, which is defined here as the maximum capacity of a seaport to carry cargo, is a combined product of port capacity and related services. Port capacity planning is complicated by the presence of issues: port-commercial and public interests, competition, economies of scale, capacity and technological development. Physically expanding the port's capacity is an interesting strategy because it improves the quality of service, making the port more attractive to freight carriers, and it allows for an autonomous increase in port demand.

УДК 331.45

DOI: $10.35340 / 2308-104 X .2021 .91-2-11$

\section{ОПТИМІЗАЦІЯ ОХОРОНИ ПРАЦІ ФАХІВЦІВ ІТ-ГАЛУЗІ}

\author{
КАЛЬЯНОВ А. В., \\ доктор медичних наук, старший \\ науковий співробітник, професор \\ кафедри охорони праці й \\ навколишнього середовища \\ ДВНЗ «Приазовський державний \\ технічний університет»
}

\section{OPTIMIZATION OF OCCUPATIONAL SAFETY OF THE IT INDUSTRY SPECIALISTS}

\author{
KALYANOV A., \\ Doctor of Medical Science, Senior \\ Research Officer, Professor of the \\ Department of Labour and \\ Environmental Protection, \\ SHEl «Priazovsky State Technical \\ University»
}

Визначено проблеми та основні причини щодо відсутності належного забезпечення охорони праці в IT-галузі, окреслено негативи використання інформаційних технологій, проведена експертна оцінка впливу окремих складових на розвиток інформаційної культури ITфахівців. Запропоновано заходи щодо вдосконалення охорони праці при впровадженні нових технологій IT-галузі.

Ключові слова: охорона праці, IT-галузь, інформаційна культура, нові інформаційні технології.

Определены проблемы и основные причины отсутствия надлежащего обеспечения охраны труда в IT-отрасли, негативы использования информационных технологий, проведена экспертная оценка влияния отдельных составляющих на развитие информационной культуры IT-специалистов. Предложены меры по оптимизации охраны труда при внедрении новых технологий в IT-отрасли.

Ключевые слова: охрана труда, IT-отрасль, информационная культура, новые информационные технологии.

The problems and main reasons for the lack of adequate provision of labour protection in the IT-industry, the negative aspects of the use of information technology were determined, an expert assessment of the impact of individual components on the development of information culture 